\title{
PENGARUH KELEKATAN TERHADAP KESEJAHTERAAN PSIKOLOGIS YANG DIMEDIASI OLEH RESILIENSI PADA REMAJA DENGAN ORANG TUA BERCERAI
}

\author{
Putri Puspitasari, Sri Maslihah, Anastasia Wulandari
}

Departemen Psikologi Fakultas Ilmu Pendidikan Universitas Pendidikan Indonesia e-mail: putrip9@student.upi.edu,maslihah_psi@upi.edu,diangem2_psi@upi.edu

\begin{abstract}
The aim of this study was to examine the correlation of attachment on psychological wellbeing with resilience act as mediator. Participants were 127 high school adolescents with parent divorced while aged 0 to 12 years old. Attachment was assessed by Inventory of Parent and Peer Attachment (IPPA), resilience was assessed by Resilience Scale (RS), and psychological well-being was assessed by Psychological Well-Being Scale (PWBS) instruments. Causal mediation analyses were used to examine the proposed mediation effects. Result showed that attachment can predict adolescents' psychological well-being. On other hand, resilience functioned as a mediator on the correlation.
\end{abstract}

Keywords: attachment, psychological well-being, resilience, adolescents with divorce parent

\begin{abstract}
Abstrak
Penelitian ini bertujuan untuk melihat pengaruh kelekatan terhadap kesejahteraan psikologis dengan peran resiliensi sebagai mediator. Partisipan penelitian sebanyak 127 remaja sekolah menengah atas yang memiliki orang tua bercerai saat remaja tersebut berusia 0 sampai 12 tahun. Instrumen yang digunakan untuk mengukur kelekatan adalah Inventory of Parent and Peer Attachment (IPPA), sedangkan untuk mengukur resiliensi adalah Resilience Scale (RS), dan untuk mengukur kesejahteraan psikologis adalah Psychological Well-Being Scale (PWBS). Teknik analisis data yang digunakan adalah causal mediation analysis. Hasil yang diperoleh menunjukan kelekatan terhadap orang tua dapat memprediksi kesejahteraan psikologis. Selain itu, ditemukan bahwa resiliensi berperan sebagai mediator.
\end{abstract}

Kata kunci: kelekatan, kesejahteraan psikologis, resiliensi, remaja dengan orang tua bercerai

\section{PENDAHULUAN}

Keluarga merupakan dua orang atau lebih individu yang terikat hubungan darah, hubungan pernikahan atau pengangkatan, serta hidup dalam satu rumah tangga, yang saling berinteraksi satu sama lain, dan berperan serta dalam menciptakan kebudayaan (Friedman, 2010). Keluarga merupakan lingkungan pertama dan utama yang menanamkan nilai-nilai kehidupan pada seseorang. Idealnya dalam setiap keluarga 
terdapat orang tua yang lengkap beserta dengan anak. Akan tetapi kenyataannya tidak semua keluarga memiliki orang tua yang masih utuh dan tinggal bersama. Hal tersebut dapat disebabkan salah satunya oleh perceraian. Perceraian sendiri menurut UU Republik Indonesia Nomor 1 tahun 1974 pasal 38 adalah salah satu jenis dari putusnya perkawinan antara suami istri yang terikat dalam ikatan yang sah. Perceraian tidak hanya berdampak negatif kepada pasangan suami istri, tetapi juga pada anak.

Perceraian menimbulkan dinamika psikologis pada seorang anak, terlebih pada remaja yang sudah dapat mengerti apa arti perpisahan kedua orang tuanya serta dampaknya (Dagun, 2013). Remaja yang orang tuanya bercerai cenderung kurang dapat beradaptasi dengan baik dibandingkan remaja yang tidak mengalami hal serupa (Collins \& Laursen, 2013). Remaja dapat mengalami distres, lebih lanjutnya dapat mengalami kecemasan dan depresi akibat hal tersebut (Storksen dkk, 2006).

Selain hal-hal yang telah dijelaskan di atas, perceraian orang tua juga memiliki dampak terhadap kesejahteraan psikologis remaja (Amato \& Booth, 1991). Kesejahteraan psikologis sendiri adalah optimalisasi manusia kearah positif yang bertujuan untuk memperoleh hidup yang bermakna (Lopez, 2009; Ryff, 1989). Remaja dengan latar belakang keluarga utuh memiliki nilai kesejahteraan psikologis yang lebih tinggi daripada remaja dengan orang tua yang bercerai (Aminah dkk, 2012). Amato \& Booth (1991) menemukan bahwa individu yang mengalami perceraian orang tua ketika kecil menunjukkan adanya kesejahteraan yang rendah ketika mereka dewasa, dibandingkan individu lain yang tidak mengalami hal serupa.

Kelekatan menjadi salah satu cara untuk menjabarkan perihal orang tua dan individu dalam konteks perceraian dan bagaimana individu memaknai pengalamannya tersebut (Feeney \& Monin, 2008). Kelekatan sendiri adalah ikatan emosional yang kuat antara keduanya di seluruh rentang usia dan sifatnya kekal (Ainsworth, 1969). Kelekatan dikembangkan oleh individu dimulai saat bayi dengan figur kelekatannya, yakni orang tua dan menjadi sumber kenyamanan dan keamanan diri dalam menghadapi ancaman dari lingkungan sekitarnya (Bowlby, 1973). Kelekatan menjadi dasar pemahaman strategi regulasi emosi yang digunakan individu saat menghadapi perceraian orang tua; tentu tiap individu akan memiliki reaksi yang berbeda-beda, tergantung pada pola kelekatan yang dimilikinya (Feeney \& Monin, 2008).

Peristiwa perceraian orang tua merupakan suatu peristiwa buruk yang dapat terjadi pada remaja, akan tetapi respon yang diberikan tentu berbeda dalam menyikapi perceraian orang tua (Karina, 2014). Melihat hal ini, remaja perlu memiliki kemampuan adaptasi dalam menghadapi situasi tersebut sebagai pemelihara diri sehingga tidak berubah menjadi individu yang maladaptif (Bowlby, 1988). Proses untuk mampu beradaptasi dari masa sulit tersebut membutuhkan kekuatan dari dalam diri, optimisme, serta fleksibilitas sehingga individu dapat bangkit dari keadaan sulit, yang mana hal tersebut dinamakan resiliensi (Compton, 2005; Lopez, 2009; Masten, 2001; Sagone \& De Caroli, 2014b; Wagnild, 2009; Wagnild \& Young, 1993). 
Resiliensi pada dasarnya dimiliki setiap orang, termasuk remaja, di mana setiap orang mampu belajar menghadapi kondisi yang tidak menyenangkan dalam hidupnya meskipun keadaannya sulit (Benard, 1991). Resiliensi membantu mengurangi stres dan memelihara kesejahteraan psikis individu (Reivich \& Shatté, 2002; Seligman dkk, 2005). Remaja yang resilien bukan berarti tidak pernah mengalami kesulitan atau distres (Southwick \& Charney, 2012), melainkan remaja dapat pulih kembali dengan lebih cepat dari keadaan buruk yang ada (Sagone \& De Caroli, 2014b). Hal tersebut dapat terjadi karena resiliensi membuat individu memandang dan memperlakukan masalah dengan perasaan yang tidak emosional, tetap mengekspresikan perasaannya, mencoba mencari kedekatan dengan yang lain, serta berinteraksi aktif dengan orang lain, hal ini menyebabkan dirinya mampu bertahan menghadapi stres (Karreman \& Vingerhoets, 2012).

Berdasarkan hal-hal yang telah dijelaskan di atas peneliti tertarik untuk meneliti apakah kelekatan dapat memprediksi kesejahteraan psikologis. Selain itu, peneliti juga tertarik untuk meneliti apakah resiliensi memediasi peran kelekatan terhadap kesejahteraan psikologis.

\section{Kelekatan}

Bowlby mengidentifikasikan bahwa perilaku kelekatan adalah segala bentuk perilaku yang merupakan hasil dari kedekatan yang didapatkan oleh individu dari individu lainnya yang dianggap lebih mampu mengatasi berbagai hal di kehidupan (Bowlby, 1982). Bowlby (1977) menyebutkan bahwa kelekatan merupakan kecenderungan individu untuk memiliki ikatan afeksi yang kuat terhadap individu tertentu. Bowlby menyebutkan hal penting dari teori ini adalah hubungan antara individu utama yang merawat (caregiver-biasanya ibu) terhadap bayinya, hal tersebut terbentuk akibat dari interaksi timbal balik yang terjadi dan menciptakan adanya rasa aman serta terlindungi bagi bayi (Bowlby, 1977). Pengalaman ketika masa kanak-kanak awal ini menjadi landasan bagi individu dalam menciptakan internal working model terhadap dunianya, dirinya sendiri, orang lain, maupun hubungan lainnya di masa mendatang (Bowlby, 1977). Kelekatan dapat diukur dengan skala melalui dimensi trust, communication, dan alienation.

\section{Resiliensi}

Wagnild \& Young (1993) meyebutkan bahwa resiliensi adalah kemampuan untuk pulih dari keadaan sulit (adversity) dan suatu karakteristik individu yang mampu beradaptasi dan bertahan maupun bangkit dari keadaan penuh hambatan. Di dalamnya terdapat kekuatan dalam diri, kompetensi, optimisme, fleksibilitas, dan kemampuan untuk mengatasi masalah dengan efektif (Wagnild, 2009). Individu dapat dikatakan memiliki resiliensi apabila perkembangan dirinya berada dalam posisi beresiko akan 
tetapi hal tersebut tidak memengaruhi dirinya (Ruvalcaba-Romero dkk, 2014). Dengan kata lain, individu yang resilien akan lebih mampu menghadapi kesulitan, bertindak lebih adaptif dengan hal tersebut dan dapat bertahan setelah penderitaan tersebut di alami (Cutuli \& Masten, 2009). Resiliensi diukur menggunakan skala melalui dimensi perseverance, equanimity, meaningfulness, self-reliant, dan existential aloneness.

Kesejahteraan Psikologis

Kesejahteraan psikologis merupakan usaha untuk megoptimalkan potensi diri kearah positif (positive psychological functioning) (Ryff, 1989). Ryan \& Deci (2001) berpendapat bahwa kesejahteraan psikologis merujuk kepada konstruk yang berkaitan dengan pengoptimalan pemungsian aspek positif dari individu. Sedangkan menurut Sagone \& De Caroli (2014a) bahwa kesejahteraan psikologis termasuk kepada dimensi yang berkaitan dengan resiliensi dan ketahanan diri (hardiness). Hal tersebut diukur dengan menggunakan skala melalui dimensi self-acceptance, positive relations with others, autonomy, environmental mastery, purpose in life, dan personal growth.

\section{METODE}

\section{Desain Penelitian}

Metode yang akan digunakan pada penelitian ini adalah metode pendekatan kuantitatif. Penelitian ini menggunakan desain penelitian korelasional untuk mengetahui pengaruh kelekatan ibu (X1), kelekatan ayah (X2), kesejahteraan psikologis (Y), dan resiliensi $(Z)$ pada remaja yang orang tuanya bercerai di Kota Bandung.

\section{Populasi dan Sampel Penelitian}

Populasi pada penelitian ini adalah remaja di Kota Bandung. Pengambilan sampel menggunakan teknik non-probability sampling dengan purposive sampling, yakni dengan kriteria remaja yang orang tuanya bercerai saat remaja berusia 0-12 tahun. Peneliti menggunakan rule of thumb untuk menentukan sampel, di mana sampel berjumlah 124 orang (Cohen \& Cohen, 1975).

\section{Instrumen penelitian}

Peneliti menggunakan kuesioner sebagai instrumen alat ukur dalam penelitian ini. Instrumen yang digunakan untuk mengukur kelekatan adalah Inventory of Parent and Peer Attachment (IPPA) dari Armsden \& Greenberg (2009) yang telah dimodifikasi oleh Maharani (2018). The Parental Attachment Section terdiri dari 25 item ayah dan 25 item ibu dengan total 50 item berupa penyataan mengenai persepsi kelekatan dengan orang tua. Terdapat tiga dimensi di dalamnya yaitu trust, communication, dan 
alienation. Respon menggunakan skala 5 poin Likert, dengan rentang Tidak Pernah (1), Sangat Jarang (2), Jarang (3), Sering (4), dan Sangat Sering (5).

Instrumen yang digunakan untuk mengukur resiliensi adalah Resilience Scale dari Wagnild \& Young (1993) yang dimodifikasi oleh Harning (2018). Resilience Scale memiliki lima dimensi berupa ketenangan hati, kegigihan, kemandirian, kebermaknaan hidup, dan eksistensi diri yang diwakili oleh 24 item. Skala terdiri dari rentang skor 1 (Sangat Tidak Sesuai), skor 2, skor 3, skor 4, skor 5, skor, dan skor 7 (Sangat Sesuai).

Instrumen yang digunakan untuk mengukur kesejahteraan psikologis adalah Psychological Well-Being Scale (PWBS) oleh Ryff (1989) terdiri dari 42 item. Peneliti melakukan alih bahasa ke dalam Bahasa Indoensia dan melakukan try out sebanyak satu kali. Terdapat enam dimensi dalam PWB yakni self-acceptance, positive relations with others, autonomy, environmental mastery, purpose in life, dan personal growth. Instrumen ini menggunakan rating scale. Terdiri dari skor 1 (Sangat Tidak Setuju), skor 2, skor 3, skor 4, skor 5, hingga skor 6 (Sangat Setuju).

\section{HASIL}

Gambaran Umum Subyek

Tabel 1

Gambaran Umum Kesejahteraan Psikologis Subyek

\begin{tabular}{|c|c|c|c|c|}
\hline $\begin{array}{c}\text { Kesejahteraan } \\
\text { Psikologis }\end{array}$ & Rentang Skor & $f$ & Persentase & Akumulasi \\
\hline Sangat Tinggi & $187-235$ & 16 & $12.6 \%$ & \multirow[t]{2}{*}{$84.3 \%$} \\
\hline Tinggi & $138-186$ & 91 & $71.7 \%$ & \\
\hline Rendah & 89-137 & 20 & $15.7 \%$ & \multirow[t]{2}{*}{$15.7 \%$} \\
\hline Sangat Rendah & $39-88$ & 0 & $0 \%$ & \\
\hline & Juml & 127 & & \\
\hline
\end{tabular}

Berdasarkan tabel 1 sebanyak 84,3\% subyek memiliki kesejahteraan psikologis tinggi. Sedangkan sisanya sebesar $15,7 \%$ subyek memiliki kesejahteraan psikologis yang rendah.

\section{Pengaruh Kelekatan terhadap Kesejahteraan Psikologis}

Tabel 2 menunjukkan bahwa signifikansi Kelekatan Ibu terhadap Kesejahteraan Psikologis sebesar 0.000. Nilai ini termasuk $\alpha<0.05$ yang artinya kelekatan ibu secara signifikan mempengaruhi kesejahteraan psikologis. Kelekatan Ibu memiliki kontribusi sebesar 22.6\% (R-Square: 0.226) dalam menjelaskan kesejahteraan psikologis yang dialami partisipan. Dengan demikian, terdapat $77.4 \%$ prediktor (variabel independen lain) yang dapat memengaruhi kesejahteraan psikologis. Di samping itu, pada tabel 2 
koefisien regresinya bernilai positif sebesar 0.663 , maka dari itu dapat dikatakan apabila terjadi penambahan skor pada kelekatan ibu maka skor kesejahteraan psikologis akan turut bertambah.

Tabel 2

Hasil Analisis Pengaruh Kelekatan terhadap Kesejahteraan Psikologis

\begin{tabular}{lllll}
\hline & B & R & R Square & Sig. \\
\hline Konstanta & 110.865 & & & 0.000 \\
\hline Kelekatan Ibu & 0.663 & 0.475 & 0.226 & 0.000 \\
\hline Konstanta & 123.037 & & & 0.000 \\
\hline Kelekatan Ayah & 0.498 & 0.418 & 0.174 & 0.000 \\
\hline
\end{tabular}

Hasil pada tabel 2 juga menunjukkan bahwa signifikansi Kelekatan Ayah terhadap Kesejahteraan Psikologis sebesar 0.000. Nilai ini termasuk $\alpha<0.05$ yang artinya kelekatan ayah secara signifikan mempengaruhi kesejahteraan psikologis anak. Kelekatan Ayah memiliki kontribusi sebesar 17.4\% (R-Square: 0.174) dalam menjelaskan kesejahteraan psikologis yang dialami anak. Dengan demikian, terdapat $82.6 \%$ prediktor (variabel independen) lain yang dapat memengaruhi kesejahteraan psikologis. Di samping itu, pada tabel 2 koefisien regresinya bernilai positif sebesar 0.498, maka dari itu dapat dikatakan apabila terjadi penambahan skor pada Kelekatan Ayah maka skor kesejahteraan psikologis anak akan turut bertambah.

Pengaruh Kelekatan terhadap Resiliensi

Tabel 3

Hasil Analisis Pengaruh Kelekatan terhadap Resiliensi

\begin{tabular}{lcccc}
\hline & B & R & R Square & Sig. \\
\hline Konstanta & 93.288 & & & 0.000 \\
\hline Kelekatan Ibu & 0.391 & 0.330 & 0.109 & 0.000 \\
\hline Konstanta & 123.037 & & & 0.000 \\
\hline Kelekatan Ayah & 0.498 & 0.418 & 0.174 & 0.000 \\
\hline
\end{tabular}

Tabel 3 menunjukkan bahwa signifikansi kelekatan ibu terhadap resiliensi sebesar 0.000. Nilai ini termasuk $\alpha<0.05$ yang artinya kelekatan ibu secara signifikan mempengaruhi resiliensi anak. Kelekatan ibu memiliki kontribusi sebesar 10.9\% (RSquare: 0.109) dalam menjelaskan resiliensi anaknya. Dengan demikian, terdapat $89.1 \%$ prediktor (variabel independen) lain yang dapat memengaruhi resiliensi. Di samping itu, pada tabel 3 koefisien regresinya bernilai positif sebesar 0.391, maka dari itu dapat dikatakan apabila terjadi penambahan skor pada kelekatan ibu maka skor resiliensi akan turut bertambah.

Tabel 3 juga menunjukkan bahwa signifikansi kelekatan ayah terhadap resiliensi sebesar 0.000 . Nilai ini termasuk $\alpha<0.05$ yang artinya kelekatan pada ayah secara 
signifikan mempengaruhi resiliensi. Kelekatan ayah memiliki kontribusi sebesar $16 \%$ (R-Square: 0.160) dalam menjelaskan resiliensi yang dialami anak. Dengan demikian, terdapat $84 \%$ prediktor (variabel independen)lain yang dapat memengaruhi resiliensi. Di samping itu, pada tabel 3 koefisien regresinya bernilai positif sebesar 0.405 , maka dari itu dapat dikatakan apabila terjadi penambahan skor pada Kelekatan Ayah maka skor resiliensi anak akan turut bertambah.

Pengaruh Resiliensi terhadap Kesejahteraan Psikologis

Tabel 4

Analisis Regresi Pengaruh Resiliensi terhadap Kesejahteraan Psikologis

\begin{tabular}{lllll}
\hline & B & R & R Square & Sig. \\
\hline Konstanta & 75.597 & & & 0.000 \\
Resiliensi (Z) & 0.692 & 0.588 & 0.346 & 0.000 \\
\hline
\end{tabular}

Tabel 4 menunjukkan bahwa signifikansi resiliensi terhadap Kesejahteraan Psikologis sebesar 0.000. Nilai ini termasuk $\alpha<0.05$ yang artinya resiliensi secara signifikan mempengaruhi kesejahteraan psikologis. Resiliensi memiliki kontribusi sebesar 34.6\% (R-Square: 0.346) dalam menjelaskan kesejahteraan psikologis yang dialami partisipan. Dengan demikian, terdapat $65.4 \%$ prediktor (variabel independen) lain yang dapat memengaruhi kesejahteraan psikologis. Di samping itu, pada tabel 4 koefisien regresinya bernilai positif sebesar 0.692 , maka dari itu dapat dikatakan apabila terjadi penambahan skor pada Resiliensi maka skor kesejahteraan psikologis akan turut bertambah.

Pengaruh Kelekatan terhadap Kesejahteraan Psikologis yang dimediasi oleh Resiliensi

Tabel 5

Hasil Analisis Pengaruh Kelekatan Ibu terhadap Kesejahteraan Psikologis yang Dimediasi oleh Resiliensi

\begin{tabular}{ccccc}
\hline & B & R & R Square & Sig. \\
\hline Konstanta & 57.725 & & & 0.000 \\
Kelekatan Ibu & 0.440 & 0.659 & 0.435 & 0.000 \\
Resiliensi & 0.570 & & & 0.000 \\
\hline
\end{tabular}

Tabel 5 menunjukkan bahwa angka signifikansi sebesar 0.000. Nilai ini termasuk $\alpha<0.05$ yang artinya pengaruh kelekatan ibu dan resiliensi terhadap kesejahteraan psikologis tetap signifikan. Berdasarkan tabel 5 , koefisien regresi kelekatan ibu $\left(\mathrm{X}_{1}\right)$ terhadap kesejahteraan psikologis (Y) sebesar $b=0.440$. Sedangkan koefisien regresi resiliensi terhadap variabel $\mathrm{Y}$ sebesar $b=0.570$. 
Tabel 6

Pengaruh Kelekatan Ayah terhadap Kesejahteraan Psikologis yang Dimediasi oleh Resiliensi

\begin{tabular}{ccccc}
\hline & B & R & R Square & Sig. \\
\hline Konstanta & 68.708 & & & 0.000 \\
Kelekatan Ayah & 0.258 & 0.621 & 0.385 & 0.006 \\
Resiliensi & 0.590 & & & 0.000 \\
\hline
\end{tabular}

Tabel 6 menunjukkan bahwa angka signifikansi sebesar 0.000. Nilai ini termasuk $\alpha<0.05$ yang berarti pengaruh kelekatan ayah dan resiliensi terhadap kesejahteraan psikologis tetap signifikan. Berdasarkan tabel 6 , koefisien regresi kelekatan ayah $\left(\mathrm{X}_{2}\right)$ terhadap kesejahteraan psikologis (Y) sebesar $b=0.258$. Sedangkan koefisien regresi resiliensi terhadap variabel Y sebesar $b=0.590$.

\section{PEMBAHASAN}

Kesejahteraan psikologis pada hakikatnya adalah keadaan individu yang mampu mengoptimalkan diri dalam kondisi yang baik dan buruk (Ryan \& Deci, 2001). Hal ini membuat kesejahteraan psikologis menjadi suatu hal yang penting dalam perkembangan hidup individu (Vinayak \& Judge, 2018). Akan tetapi Amato \& Keith (1991) dan Van Wel, dkk (2000) menemukan bahwa perceraian menyebabkan kesejahteraan yang rendah pada anak di keluarga yang bercerai dibanding dengan remaja pada keluarga yang utuh. Penelitian ini bermaksud untuk mengetahui pengaruh kelekatan terhadap kesejahteraan psikologis remaja dengan orang tua bercerai yang dimediasi oleh resiliensi. Hasil penelitian ini berbeda dengan penelitian Amato \& Keith (1991) dan Van Wel, dkk (2000) tersebut, dikarenakan hasil analisis menunjukkan tingkat kesejahteraan psikologis pada subjek remaja SMA dengan orang tua yang sudah bercerai di Kota Bandung berada pada kategori tinggi dengan akumulasi 84.3\%, sedangkan kategori rendah akumulasinya hanya 15.7\% (lihat tabel 4.9).

Kesejahteraan psikologis yang tinggi pada penelitian ini menunjukkan bahwa remaja SMA dengan orang tua yang bercerai di Kota Bandung memiliki kemampuan pengambilan keputusan yang baik, bertindak secara pasti, memiliki resistensi terhadap tekanan sosial yang diterimanya, mampu bertindak sesuai kehendak diri, serta menerima kekurangan dan kelebihan pada dirinya (Ryff, 2013). Di samping itu, percaya terhadap kemampuan diri, melihat bahwa dirinya terus berkembang dan mampu memanfaatkan peluang yang ditemuinya, mempunyai relasi yang baik, hangat, dan berlandaskan rasa percaya dengan orang lain, lalu mampu mengerti dan berempati terhadap orang lain, serta memiliki tujuan yang ingin dicapai olehnya (Ryff, 2013).

Adanya kesejahteraan psikologis yang tinggi pada remaja yang orangtuanya bercerai disebabkan oleh adanya resiliensi yang berperan di dalamnya, sejalan dengan hasil uji subhipotesis penelitian yang menunjukkan bahwa resiliensi berpengaruh positif 
terhadap kesejahteraan psikologis $(b=0.692$, sig. 0.000$)$. Hasil penelitian ini mendukung penelitian sebelumnya yang menyebutkan bahwa resiliensi berperan penting di dalam kesejahteraan psikologis individu (Akbari \& Khormaiee, 2015; Harms dkk, 2018; Souri \& Hasanirad, 2011; Wagnild, 2009). Selain itu, hasil penelitian ini mendukung hasil penelitian lain yang menunjukkan resiliensi merupakan prediktor positif dan faktor protektif terhadap kesejahteraan psikologis individu (Akbari \& Khormaiee, 2015; Harms dkk, 2018; Souri \& Hasanirad, 2011; Wagnild, 2009), dan setiap orang mampu memilikinya (Benard, 1991).

Melalui resiliensi remaja mampu menyesuaikan tindakan yang akan diambil secara efektif agar dapat mengatasi rasa tidak nyaman, stres, dan hal negatif yang dialami (Cutuli \& Masten, 2009; Ruvalcaba-Romero dkk, 2014). Remaja yang resilien mampu beradaptasi dalam berbagai kondisi dan mampu bangkit dari keterpurukan yang dialami dengan relatif lebih cepat dibandingkan individu lain yang merasakan hal sama (Rutter, 2013; Wagnild, 2009). Resiliensi inilah yang bertanggung jawab di dalam ketahanan diri remaja (Karreman \& Vingerhoets, 2012).

Peristiwa perceraian orang tua tersebut mengharuskan adanya penyesuaian terhadap perubahan keluarga yang besar pada diri individu (Collins \& laursen, 2013). Penyesuaian tersebut cenderung tidak adaptif seperti menjauhi keluarga, menarik diri, maupun bersikap asing terhadap orang tua sebagai bentuk respons terhadap peristiwa tersebut (Hetherington dkk, 1992). Dampak negatif lain dapat timbul seperti merasa kesepian, adanya rasa tidak bahagia, mengalami kecemasan, serta perasaan tidak aman (Steven \& Black, 1995). Perpisahan orang tua dapat meningkatkan resiko psikologis yang buruk pada diri remaja (Dewi \& Hamidah, 2013). Di sinilah resiliensi berperan sebagai pelindung remaja dari berbagai akibat negatif tersebut (De Caroli \& Sagone, 2016).

Menjadi remaja yang resilien berarti berusaha melewati pengalaman tidak menyenangkan atau menyulitkan serta dapat memaknai hal tersebut dan menjadikannya sebagai pembelajaran hidup (Kotzé \& Kleynhans, 2014). Resiliensi yang tinggi pada penelitian ini menunjukkan bahwa remaja SMA dengan orang tua yang bererai di Kota Bandung berupaya mencari tahu sesuatu yang tidak mereka pahami, menghadapi konsekuensi atas tindakan mereka serta menyesuaikan perilaku berdasarkan situasi (De Caroli \& Sagone, 2016). Di samping itu mereka pun cenderung menghindar dari situasi yang dapat membuatnya terlibat masalah dan belajar dari kesalahan yang pernah dilakukan, lalu mengetahui hal apa yang mereka kuasai, serta cenderung untuk melihat sisi positif dari suatu kejadian, dan menanganinya dengan menyelipkan sisi humor (De Caroli \& Sagone, 2016).

Lebih singkatnya resiliensi menjadi sarana bagi remaja berpikir secara kreatif dalam mencari pemecahan masalah, dapat melihat sesuatu dari sudut pandang berbeda, serta tetap mampu menjalani kesehariannya walaupun sedang mengahadapi kesulitan (Vinothkumar \& Prasad, 2017). Oleh karena itu, remaja dengan orang tua bercerai di 
Kota Bandung mampu menjaga agar tidak terpengaruh oleh hal buruk dan terhindarkan dari burnout atau lelah secara psikis yang mampu berdampak negatif terhadap kesejahteraan psikologisnya (Kotzé \& Kleynhans, 2014).

Resiliensi dalan penelitian ini berperan sebagai penghubung antara kelekatan dengan kesejahteraan psikologis. Berbicara mengenai kelekatan, hasil penelitian ini menguji kelekatan orang tua menjadi kelekatan ibu dan kelekatan ayah secara terpisah. Kelekatan yang tergolong pada kategori tinggi ini termasuk pada pola kelekatan aman (secure attachment) (Ma \& Huebner, 2008). Terdapat perbedaan antar orang tua dalam hasil penelitian ini, akan tetapi hal tersebut tidak berbeda jauh. Kelekatan terhadap ibu maupun ayah sama-sama memberikan sumber rasa aman dan nyaman bagi diri remaja (Wahyuni \& Asra, 2014). Di samping itu, kelekatan turut membentuk fondasi kepercayaan remaja terhadap orang lain (Collins \& Read, 1990). Landasan rasa aman tersebut dapat melahirkan kemampuan remaja dalam mengembangkan hubungan yang baik dengan dirinya sendiri dan dengan orang lain, menyebabkan munculnya rasa puas akan relasi dan timbul kemandirian secara emosional namun tetap mampu mencari dukungan dan kedekatan dengan orang sekitarnya di saat dirinya menghadapi situasi yang tidak menyenangkan (Mikulincer \& Shaver, 2003).

Kelekatan terhadap orang tua yang aman memberikan pandangan bahwa remaja tersebut merasa dirinya cukup dan tidak memerlukan validasi dari orang luar (Simon \& Baxter, 1993). Kelekatan yang aman pada penelitian ini menunjukkan bahwa remaja SMA dengan orang tua yang bercerai di Kota Bandung memiliki perasaan aman akan dirinya, ditunjukkan oleh pandangan yang positif terhadap diri maupun orang lain, menyebabkan adanya perasaan bahwa dirinya itu berharga, dan mampu mengembangkan ekspektasi yang baik pada orang lain bahwa mereka mampu responsif pada dirinya dan menghindarkan diri dari rasa kecewa akibat pengharapan yang tidak realistis (Bartholomew \& Horowitz, 1991).

Penelitian ini menunjukkan bahwa resiliensi secara efektif memengaruhi pengaruh kelekatan terhadap kesejahteraan psikologis. Oleh karena itu, dapat disimpulkan bahwa remaja dengan orang tua yang bercerai di Kota Bandung memiliki tingkat kesejahteraan psikologis yang tinggi walaupun pernah mengalami perceraian orang tua di masa kanakkanak. Di samping itu mereka memiliki tingkat resiliensi yang tinggi pada penelitian ini. Temuan ini membuktikan hipotesis utama yang menyebutkan bahwa resiliensi dapat memediasi pengaruh kelekatan ibu terhadap kesejahteraan psikologis dan pengaruh kelekatan ayah terhadap kesejahteraan psikologis. Maka dari itu ketika remaja memiliki resiliensi yang tinggi, hal ini dapat mendukung kelekatan terhadap orang tua sehingga remaja mampu memiliki kesejahteraan psikologis. 


\section{DAFTAR PUSTAKA}

Akbari, A., \& Khormaiee, F. (2015). The Prediction of Mediating Role of Resilience Between Psychological Well-Being and Emotional Intelligence in Students. International Journal of School Health, 2(3), 1-5.

Amato, P R, \& Keith, B. (1991). Parental divorce and the well-being of children: a meta-analysis. Psychological Bulletin, 110(1), 26-46. https://doi.org/10.1037/00332909.110.1.26

Amato, Paul R, \& Booth, A. (1991). Consequences of parental divorce and marital unhappiness for adult well-being. Social Forces, 69(3), 895-914. https://doi.org/10.1093/sf/69.3.895

Aminah, Andayani, T. R., \& Karyanta, N. A. (2004). Proses Penerimaan Anak (Remaja Akhir) terhadap Perceraian Orangtua dan Konsekuensi Psikososial yang Menyertainya.

Bowlby, J. (1973). Attachment and Loss: Separation, Anxiety and Anger (Vol. II). United States: Basic Books. https://doi.org/0-465-07691-2 Cloth

Bowlby, J. (1988). A Secure Base: Parent-Child Attachment and Healthy Human Development (Vol. 178). United States: Basic Books. https://doi.org/10.1097/00005053-199001000-00017

Collins, W. A., \& Laursen, B. (2013). Parent-Adolescent Relationships and Influences. In R. M. Lerner \& L. Steinberg (Eds.), Handbook of Adolescent Psychology (Vol. 1, pp. 331-361). New York and London: Wiley \& Sons. https://doi.org/10.1002/9780471726746.ch11

De Caroli, M. E., \& Sagone, E. (2016). Resilience and Psychological Well-Being: Differences for Affective Profiles in Italian Middle and Late Adolescents. International Journal of Developmental and Educational Psychology, 1(1), 149160. https://doi.org/10.17060/ijodaep.2016.n1.v1.237

Feeney, B. C., \& Monin, J. K. (2008). An Attachment-Theoretical Perspective on Divorce. In J. Cassidy \& P. R. Shaver (Eds.), Handbook of attachment: Theory, Research, and Clinical Applications (Second Edi, pp. 934-957). New York: Guilford Press.

Harms, P., Brady, L., Wood, D., \& Silard, A. (2018). Resilience and Well-Being. In E. Diener, S. Oishi, \& L. Tay (Eds.), Handbook of Well-Being (pp. 1-12). Salt Lake City: DEF Publishers. 
Karreman, A., \& Vingerhoets, A. J. J. . (2012). Attachment and well-being: The mediating role of emotion regulation and resilience. Personality and Individual Differences, 53(7), 821-826. https://doi.org/10.1016/j.paid.2012.06.014

Kotzé, M., \& Kleynhans, R. (2014). Psychological Well-Being and Resilience as Predictors of First-Year Students' Academic Performance. Journal of Psychology in Africa, 23(1), 51-59. https://doi.org/10.1080/14330237.2013.10820593

Ma, C. Q., \& Huebner, E. S. (2008). Attachment relationships and adolescents' life satisfaction: some relationships matter more to girls than boys. Psychology in the Schools, 45(2), 177-190. https://doi.org/10.1002/pits

Masten, A. S. (2001). Ordinary magic: Resilience processes in development. American Psychologist, 56(3), 227-238. https://doi.org/10.1037//0003-066X.56.3.227

Mikulincer, M., \& Shaver, P. R. (2003). The Attachment Behavioral System In Adulthood: Activation, Psychodynamics, And Interpersonal Processes. Advances in Experimental Social Psychology, 35, 53-152. https://doi.org/10.1016/S00652601(03)01002-5

Rutter, M. (2013). Annual Research Review: Resilience-clinical implications. Journal of Child Psychology and Psychiatry, 54(4), 474-487. https://doi.org/10.1111/j.14697610.2012.02615.x

Ruvalcaba-Romero, N. A., Gallegos-Guajardo, J., \& Villegas-Guinea, D. (2014). Validation of the resilience scale for adolescents (READ) in Mexico. Journal of Behavior, Health \& Social Issues, 6(2), 21-34. https://doi.org/10.5460/jbhsi.v6.2.41180

Ryan, R. M., \& Deci, E. L. (2001). On Happiness and Human Potentials: A Review of Research on Hedonic and Eudaimonic Well-Being. Annual Reviews Psychology, 52, 141-166.

Ryff, C. D. (1989). Happiness is everything, or is it? Explorations on the meaning of psychological well-being. Journal of Personality and Social Psychology, 57(6), 1069-1081. https://doi.org/10.1037/0022-3514.57.6.1069

Ryff, C. D. (2013). Psychological well-being revisited: Advances in the science and practice of eudaimonia. Psychotherapy and Psychosomatics, 83(1), 10-28. https://doi.org/10.1159/000353263

Sagone, E., \& De Caroli, M. E. (2014). A Correlational Study on Dispositional Resilience, Psychological Well-being, and Coping Strategies in University Students. American Journal of Educational Research, 2(7), 463-471. https://doi.org/10.12691/education-2-7-5 
Souri, H., \& Hasanirad, T. (2011). Relationship between resilience, optimism and psychological well-being in students of medicine. Procedia - Social and Behavioral Sciences, 30, 1541-1544. https://doi.org/10.1016/j.sbspro.2011.10.299

Southwick, S. M., \& Charney, D. S. (2012). The Science of Resilience: Implications for the Prevention and Treatment of Depression. Science, 338, 79-82. https://doi.org/10.1126/science. 1222942

Storksen, I., Roysamb, E., Holmen, T. L., \& Tambs, K. (2006). Adolescent Adjustment and Well-Being: Effects of Parental Divorce adn Distress. Scandinavian Journal of Psychology, 47, 75-84. https://doi.org/10.1111/j.1467-9450.2006.00494.x

van Wel, F., Linssen, H., \& Abma, R. (2000). The parental bond and the well-being of adolescents and young adults. Journal of Youth and Adolescence, 29(3), 307-318.

Vinayak, S., \& Judge, J. (2018). Resilience and Empathy as Predictors of Psychological Wellbeing among Adolescents. International Journal of Health Sciences and Research, 8(4), 192-200.

Vinothkumar, M., \& Prasad, N. (2017). Moderating role of resilience in the relationship between grit and psychological well-being. International Journal of Psychology and Psychiatry, 4(2), 10-23. https://doi.org/10.5958/2320-6233.2016.00009.2

Wagnild, G. (2009). A Review of the Resilience Scale. Journal of Nursing Measurement, 17(2), 105-113. https://doi.org/10.1891/1061-3749.17.2.105

Wagnild, G. M., \& Young, H. M. (1993). Development and Psychometric Evaluation of the Resilience Scale. Journal of Nursing Measurement, 1(2), 165-178. https://doi.org/10.1016/j.apnu.2010.05.001 